\title{
DAILY HEMATOLOGIC ASSESSMENT DURING A 230-KM MULTISTAGE ULTRAMARATHON
}

\author{
AVALIAÇÃO HEMATOLÓGICA DIÁRIA DURANTE UMA ULTRAMARATONA DEMÚLTIPLOS \\ ESTÁGIOS DE 23O KM
}

EVALUACIÓN HEMATOLÓGICA DIARIA DURANTE UNA ULTRAMARATÓN DE MÚLTIPLES ETAPAS DE 230 KM

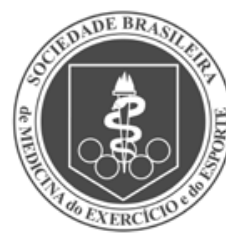

Original Article ARTIGo ORIGINAL Artículo Original

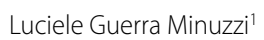

(Physical Education Professional)

Ana Maria Teixeira'

(Biochemist)

Humberto Moreira Carvalho² (Physical Education Professional)

Ricardo José da Costa ${ }^{3}$

(Physical Education Professional)

Luis Rama

(Physical Education Professional)

1. Universidade de Coimbra, Faculty of Sports Science and Physical

Education, Portugal.

2. Universidade de Campinas, Faculdade de Educação Física, São Paulo, SP, Brazil.

3. Monash University, Department of Nutrition, Dietetics and Food, Notting Hill, Australia.

\section{Correspondence:}

Estádio Universitário, Pavilhão III, Santa Clara, Coimbra, Portugal. 3040-156. lucielegm@gmail.com

\begin{abstract}
Introduction: The popularity of ultra-endurance events is increasing worldwide. However, information about hematological parameters during repeated bouts of long-duration running, such as stages during a multi-stage ultramarathon (MSUM) is scarce. Objective: The purpose of the study was to monitor daily hematologic assessment in a 230-km multistage ultramarathon (MSUM) in hot environmental conditions. Methods: Eleven male and three female $(n=14)$ ultra-endurance runners entered this MSUM, which was conducted over five stages, covering a total distance of $230 \mathrm{~km}$ in hot ambient conditions. Peripheral blood samples were collected before and after each stage to determine leukocyte and erythrocytes parameters. Results: Multilevel modelling considering all measurement points showed an increase for whole blood leukocyte and granulocyte counts at five stages of the MSUM and for monocytes until Stage 3 of the race. For erythrocyte parameters, decreases across stages were observed in hemoglobin concentration and hematocrit responses when computing/considering all measurement points. Conclusions: The results indicate that MSUM in a hot environment leads to a greater impact on leukocyte population responses and platelet variation in the initial stages of the race. We suggest that athletes may have a decrease in immune function in the early stages of the MSUM, probably with some transient risk of infectious. Nevertheless, a physiological adaptation to physical exertion and heat mitigates these changes in the subsequent stages of MSUM. Level of Evidence III; Case-control study.
\end{abstract}

Keywords: Leukocytes; Erythrocytes; Running; Infection; Athletes.

\section{RESUMO}

Introdução: A popularidade dos eventos de ultra-resistência está aumentando em todo o mundo. Entretanto, faltam informações sobre os parâmetros hematológicos durante episódios repetidos de corridas de longa duração, como, por exemplo, os estágios durante uma ultramaratona de múltiplos estágios (MSUM). Objetivo: O objetivo do estudo foi monitorar a avaliação hematológica diária em uma ultramaratona de múltiplos estágios (MSUM) de 230 km sob condições climáticas quentes. Métodos: Onze corredores e três corredoras de -ultra-resistência $(n=14)$ participaram dessa MSUM, em cinco estágios, totalizando uma distância de $230 \mathrm{~km}$ sob condições climáticas quentes. As amostras de sangue periférico foram coletadas antes e após cada estágio para determinação dos parâmetros de leucócitos e eritrócitos. Resultados: O modelo multinivel considerando todos os pontos de medição apresentou um aumento na contagem de leucócitos e granulócitos do sangue total nos cinco estágios da MSUM e para os monócitos até o estágio três da competição. Para os parâmetros dos eritrócitos, foram observadas reduções através dos estágios na concentração de hemoglobina e nas respostas do hematócrito ao se contabilizar/considerar todos os pontos de medição. Conclusões: Os resultados indicam que a MSUM em condições climáticas quentes exerce um maior impacto nas respostas da população de leucócitos e na variação plaquetária nos estágios iniciais da competição. Sugerimos que os atletas podem ter uma diminuição na função imune nos estágios iniciais da MSUM, provavelmente, com algum risco transitório de infecção. No entanto, uma adaptação fisiológica para o esforço físico e calor minimiza essas alterações nos estágios seguintes da MSUM. Nível de Evidência III; Estudo caso-controle.

Descritores: Leucócitos; Eritrócitos; Corrida; Infecção; Atletas.

\section{RESUMEN}

Introducción: La popularidad de los eventos de ultra resistencia está aumentando en todo el mundo. Entretanto, faltan informaciones sobre los parámetros hematológicos durante episodios repetidos de carreras de larga duración, como por ejemplo, las etapas de una ultramaratón de múltiples etapas (MSUM). Objetivo: El objetivo del estudio fue monitorizar la evaluación hematológica diaria en una ultramaratón de múltiples etapas (MSUM) de 230 km bajo condiciones climáticas cálidas. Métodos: Once corredores y tres corredoras de ultra resistencia $(n=14)$ participaron en esa MSUM, en cinco etapas, totalizando una distancia de 230 km bajo condiciones climáticas cálidas. Las muestras de sangre periférica fueron colectadas antes y después de cada etapa para determinación de los parámetros de leucocitos y eritrocitos. Resultados: El modelo multinivel considerando todos los puntos de medición presentó un aumento en el conteo de leucocitos y granulocitos de la sangre total en las cinco etapas de la MSUM y para los monocitos hasta la etapa 3 de la competencia. Para los parámetros de eritrocitos, fueron observadas reducciones a través de las etapas 
en la concentración de hemoglobina y en las respuestas de hematocrito al contabilizar/considerar todos los puntos de medición. Conclusiones: Los resultados indican que la MSUM en condiciones climáticas cálidas ejerce un mayor impacto en las respuestas de la población de leucocitos y en la variación plaquetaria en las etapas iniciales de la competencia. Sugerimos que los atletas pueden tener una disminución en la función inmune en las etapas iniciales de la MSUM probablemente con algún riesgo transitorio de infección. Sin embargo, una adaptación fisiológica para el esfuerzo físico y el calor, minimiza esas alteraciones en las etapas siguientes de la MSUM. Nivel de Evidencia III; Estudio de caso-control.

Descriptores: Leucocitos; Eritrocitos; Carrera; Infección; Atletas.

\section{INTRODUCTION}

The popularity of ultra-endurance races is increasing worldwide, in particular ultra-marathon events. ${ }^{1,2}$ These races comprise a variety of distances within a single bout or multi-day, taking place over various days with recovery time overnight. ${ }^{3}$

The responses of haematological parameters to continuous long-duration running, such as marathon have been documented, inclusive by our laboratory. ${ }^{4-7}$ However, information about haematological parameters to repeated bouts of long-duration running, such as stages during a multi-stage ultra-marathon competition (MSUM) is absent. ${ }^{8}$ Athletes tend to have transient suppression of immune function after an intense exercise, maybe due to the impairment in neutrophil and lymphocyte function. ${ }^{6}$ Moreover, extreme endurance exercise and other stressors are associated with decreases in erythrocyte counts. ${ }^{9}$ It seems that a higher oxygen consumption and free radical generation can lead to changes in haemoglobin conformation during exercise. ${ }^{10}$ The increase in whole blood viscosity may unfavourably affect the microcirculatory blood flow and oxygen delivery to the tissues. ${ }^{11}$

Exercising in hot conditions augments circulating stress hormones, catecholamine and cytokines with associated increases in circulating leukocytes. ${ }^{12}$ Nevertheless, MSUMs are habitually performed in extreme environmental temperatures and routed over rough and (or) arid terrain. Competing in such extreme environmental conditions accelerated increases in core temperature. ${ }^{13}$ Exercise in the heat, especially if there is high humidity, can adversely affect performance and may even result in serious heat illness. ${ }^{14}$ Hyperthermia, in response to an increased metabolic heat production during strenuous exercise combined with impairment of cooling, acts as a key determinant of performance in the heat. The heat acclimatization, pre-exercise cooling and fluid ingestion are strategies supposed to attenuate the rising in core temperature, thus enhancing exercise performance. ${ }^{15}$ Thus, the understanding of the perturbations in haematological parameters stage-by-stage in a MSUM conducted in hot environmental conditions may allow interpreting immune responses to the recovery between stages, optimizing performance. At the end of the race, this responses could be useful to prevention of subsequent illness of endurance athletes. ${ }^{16}$

The purpose of the present study was to monitor changes in leukocyte and erythrocyte parameters throughout a MSUM conducted in a hot environment. It was hypothesized that a MSUM would have a detrimental effect on leukocytes, causing an inflammatory condition that together with a reduction in the number of lymphocytes could increase the risk of infection in the post-race period.

\section{MATERIALS AND METHODS}

Eleven male and three females ( $n=14$ ) out of a total of 69 ultra-endurance runners entering this MSUM volunteered to participate in the study (age $42 \pm 8 y$, stature $174 \pm 7 \mathrm{~cm}$, body mass $71.9 \pm 8.6 \mathrm{~kg}$ ). All participants gave written informed consent before the study, which received approval from the local ethics committee and conforms to the 2008 Helsinki declaration for research ethics. Coventry University Human Research Ethics Committee did not provide an ethics submission number at the date of ethics submission and review. Instead Coventry University use the research project title as the identifier.

All participants arrived at the MSUM location $\leq 48 \mathrm{~h}$ prior to the start of S1. All participant reported no illness and/or infection in the 12 weeks leading up to the MSUM. All the fourteen ultra-runners completed the $230 \mathrm{~km}$ of the MSUM.

The study was conducted during the 2011 Al Andalusia Ultimate Trail (www.alandalus-ut.com), during the second week of July, in the region of Loja, Spain. The MSUM was conducted over five stages (five days) comprising 230 km (S1: 37 km, S2: 48 km, S3: 38 km, S4: 69 km, and S5: $38 \mathrm{~km}$, respectively) in 28h17min $\pm 4 \mathrm{~h} 15 \mathrm{~min}$ (average speed: $\left.8.1 \pm 1.3 \mathrm{~km} \cdot \mathrm{h}^{-1}\right)$, conducted in hot and dry environmental conditions $\left(30^{\circ} \mathrm{C}-40^{\circ} \mathrm{C}\right.$ and $\left.31-40 \% \mathrm{RH}\right)$, which was performed on a variety of terrains, predominantly off-road trails also including steep and narrow mountain passes, and occasional road.

Running stages commenced at either 08:00 or 09:00 h. Within the hour prior to the start, pre-stage blood samples collected. Immediately post-stage and before any foods or fluids could be consumed, blood samples were re-collected. Participants were required to sit for 10 minutes before blood sampling.

Whole blood samples were collected by venepuncture without venostasis from an antecubital vein using a $21 \mathrm{G}$ butterfly syringe into one lithium heparin (Becton Dickinson, Oxford, UK) and one $\mathrm{K}_{3}$ EDTA (Becton Dickinson, Oxford, UK) vacutainer tube. Plasma volume (Pv) changes were estimated from changes in haemoglobin and haematocrit content of $\mathrm{K}_{3}$ EDTA whole blood samples (100 $\mathrm{\mu l}$ ) immediately after sample collection. Whole blood haemoglobin concentration and haematocrit were used to estimate changes in $\mathrm{P}_{\mathrm{V}}$ relative to pre-S1, established as baseline. All the blood cells counts were corrected for changes in $\mathrm{P}_{\mathrm{V}}{ }^{17}$ Whole blood cell counts were determined using a cell counter (Coulter ACT Diff, Beckham Coulter, USA).

\section{Statistical analysis}

Descriptive statistics for all dependent variables at all measurement points are presented as mean \pm standard deviation. Changes in haematological indicators responses because of the MSUM were examined using multilevel growth modelling, considering the possibility of polynomial models. At Level 1, each athlete successive measurements over time were defined by an individual change trajectory, considering both the possibility of linear (linear term) and non-linear (squared or cubic linear term) changes, and random error. At Level 2 the individual growth parameters from Level 1 were treated as outcomes that allowed examining whether athletes differed in their initial status or rates of change, and if so, what predicted that variation. The initial Level 2 model specifications were unconditional growth models that included no substantive time-invariant 
predictors, allowing each Level 1 individual growth parameter to differ randomly in terms of its population. At level 2, the constant (intercept term) linear change trajectory and squared change trajectory parameters could vary randomly (between individuals). Individual changes were expressed as percent changes (via logarithmic transformation multiplied by 100) of the dependent variables. Also, we fitted a series of nested multilevel models in which it was examined whether athletes' rate of change within each stage (pre-stage to post-stage) varied across the five stages of the competition. The exponents may be interpreted as the rate of change within each stage. The 95\% confidence limits (CL) were estimated for each effect allowing a comparison of the rate of changes between stages. Differences may be inferred when 95\% CL does not overlap. Validity of the models was examined using deviance statistics and the Akaike information criterion (AIC), that consider the different number of fitted parameters in the two model structures to be compared and by inspection on non-uniformity of residuals distribution in plots of residual vs predicted values. Significance was set at $P<0.05$. In addition to statistical inference based on a null hypothesis test, qualitative probabilistic inference about the effects on the haematological outcomes across the ultra-marathon was included. ${ }^{18}$

\section{RESULTS}

Responses of haematological indicators within stages and across the MSUM at the different time points are summarized in Table 1.

Total leukocytes count increased significantly $(P<0.001)$ on all stages $(70.65 \%, 64.18 \%, 57.13 \%, 53.67 \%$ and $42.51 \%$, respectively). (Table 2, Figure 1 - A) Interestingly, throughout the race no differences were observed for total leukocytes counts. (Table 1) The post-Stage lymphocytes counts were lower (-13.13\%) at the end of S1 compared with pre-S1 ( $P=0.029$, Table 1). However, a return to the baseline values for lymphocytes was observed after $\mathrm{S3}$. ( $P=0.009$, Table 1, Figure 1 - B)

The results showed a significant linear increase for monocytes ( $P=0.003$; Figure $1-C$ ) and a nonlinear increase for lymphocytes ( $P=0.029$ and $P=0.009$; Figure $1-A$ ) and granulocytes ( $P=0.001$ and $P=0.008$, Figure 1 - D). Significant decreases across stages were observed on haemoglobin $(P=0.010)$ and haematocrit $(P=0.003$ ) responses when accounting all measurement points. (Table 3 )

For monocytes, pre- to post-stage increases were observed in S1, S2 and S3 (75.51\%, 51.01\% and 33.48\% respectively, P<0.001). At S4 and S5 no differences were observed for monocyte counts, and the values remained higher and stable until the end of the race. Pre- to post-stage increases were also observed in all the stages for granulocytes (104.25\%, $79.66 \%, 66.81 \%, 62.31 \%$ and $71.03 \%$ respectively, $P<0.001)$.

In contrast, no differences in erythrocyte counts were seen between stages in the MSUM. ( $P=0.694$, Table 2, Figure 2 - A) Compared with pre-Stage values, increases in the platelets counts occurred on all stages (15.49\%, 16.99\%, 14.76\%, 10.15\% and 8.53\% respectively, $\mathrm{P}<0.001$, Table 2, Figure 2 - B) in MSUM. The pre- to post-stage haemoglobin concentration and haematocrit did not alter significantly between stages of the MSUM ( $P=0.791$ and $P=0.949$ respectively; Table 2, Figure 2 - C and D). However, haemoglobin concentration and haematocrit values decreased at the end of the race. ( $P=0.010$ and $\mathrm{P}=0.003$ respectively, Table 2 )

The comparison of ranges of the $95 \% \mathrm{CL}$ imply that the magnitude of increases of changes pre- to post-stage for leukocytes and monocytes tended to decrease across the MSUM. (see Table 2) However, the magnitude of changes pre- to post-stage for granulocytes decreased between S1 to S3 and was higher in S4 and S5 compared to S3. Platelets showed significant within-stage variability across the MSUM. (Table 3)

Table 1. Mean (SD) of leukocytes, leukocyte subsets and red blood cells within each stage during the ultra-marathon ( $\mathrm{n=14}$ ).

\begin{tabular}{|c|c|c|c|c|c|c|c|c|c|c|}
\hline & \multicolumn{2}{|c|}{ Stage 1} & \multicolumn{2}{|c|}{ Stage 2} & \multicolumn{2}{|c|}{ Stage 3} & \multicolumn{2}{|c|}{ Stage 4} & \multicolumn{2}{|c|}{ Stage 5} \\
\hline & Pre & Post & Pre & Post & Pre & Post & Pre & Post & Pre & Post \\
\hline Leukocytes (x109/L) & $6.0(0.9)$ & $13.1(2.0)$ & $7.0(1.60$ & $12.9(2.7)$ & $7.7(1.9)$ & $12.6(3.5)$ & $7.3(1.7)$ & $12.2(2.3)$ & $7.0(1.6)$ & $11.1(2.5)$ \\
\hline Lymphocytes (x109/L) & $2.1(0.3)$ & $1.8(0.4)$ & $2.1(0.4)$ & $2.3(0.4)$ & $2.3(0.4)$ & $2.5(0.6)$ & $2.4(0.1)$ & $2.1(0.4)$ & $1.9(0.4)$ & $1.9(0.4)$ \\
\hline Monocytes (x109/L) & $0.3(0.1)$ & $0.8(0.2)$ & $0.4(0.1)$ & $0.7(0.2)$ & $0.4(0.2)$ & $0.6(0.2)$ & $0.5(0.2)$ & $0.6(0.3)$ & $0.6(0.2)$ & $0.7(0.2)$ \\
\hline Granulocytes (x109/L) & $3.6(0.9)$ & $10.5(1.9)$ & $4.5(1.2)$ & $10.0(2.7)$ & $5.0(1.7)$ & $9.5(3.2)$ & $4.4(1.2)$ & $9.5(2.1)$ & $4.7(1.5)$ & $8.5(2.4)$ \\
\hline Erythrocytes (x109/L) & $5.1(0.4)$ & $5.1(0.6)$ & $5.0(0.6)$ & $5.2(0.6)$ & $5.3(0.8)$ & $5.4(0.7)$ & $5.6(0.7)$ & $5.4(0.6)$ & $5.4(0.8)$ & $5.4(0.6)$ \\
\hline Haemoglobin (g/dl) & $16.5(1.1)$ & $16.7(1.2)$ & $16.0(1.3)$ & $16.3(1.3)$ & $15.4(1.3)$ & $15.6(1.0)$ & $15.8(1.1)$ & $15.4(1.3)$ & $15.1(1.5)$ & $15.1(1.2)$ \\
\hline Haematocrit (g/dl) & $46.2(3.1)$ & $46.4(3.1)$ & $44.6(3.6)$ & $45.2(3.5)$ & $43.1(3.5)$ & $43.7(3.1)$ & $43.7(3.1)$ & $42.4(3.5)$ & $41.6(4.4)$ & $41.5(3.4)$ \\
\hline Platelet $\left(\times 10^{9} / \mathrm{L}\right)$ & $229.4(62.7)$ & $273.6(75.3)$ & $239.9(56.2)$ & $287.0(66.9)$ & $245.3(81.1)$ & $268.5(53.4)$ & $250.7(73.1)$ & $283.4(64.2)$ & $263.6(72.7)$ & $298.1(63.4)$ \\
\hline
\end{tabular}

values are Mean (SD).

Table 2. Multilevel regression analysis of log transformed Leukocytes, Lymphocytes, Monocytes and Granulocytes changes within- and between-stages in the multi-stage ultramarathon.

\begin{tabular}{|c|c|c|c|c|}
\hline & Leukocytes & Lymphocytes & Monocytes & Granulocytes \\
\hline \multicolumn{5}{|l|}{ Estimate (95\% Confidence Limits) } \\
\hline Intercept & $184.97(178.54 \text { to } 191.39)^{* *}$ & $69.29(61.67 \text { to } 76.91)^{* *}$ & $-109.80(-125.82 \text { to }-93.79)^{* *}$ & $125.77(115.90 \text { to } 135.65)^{* *}$ \\
\hline Between stages linear change & $0.17(-0.01$ to 0.36$)$ & $0.45(0.05 \text { to } 0.85)^{*}$ & $0.48(0.17 \text { to } 0.79)^{* *}$ & $0.91(0.38 \text { to } 1.48)^{* *}$ \\
\hline Between stages quadratic change & & $-0.01(-0.01 \text { to }-0.00)^{* *}$ & & $-0.01(-0.01 \text { to }-0.00)^{* *}$ \\
\hline \multicolumn{5}{|c|}{ Within stages slopes (pre- vs post- differences) } \\
\hline Stage 1 slope & $70.65(60.27 \text { to } 81.03)^{* *}$ & $-13.13(-23.72 \text { to } 2.53)^{*}$ & $75.51(49.69 \text { to } 101.33)^{* *}$ & $104.25(90.51 \text { to } 117.99)^{* *}$ \\
\hline Stage 2 slope & $64.18(54.73 \text { to } 73.63)^{* *}$ & $5.37(-4.59$ to 15.34$)$ & $51.01(27.54 \text { to } 74.48)^{* *}$ & $79.66(66.73 \text { to } 92.59)^{* *}$ \\
\hline Stage 3 slope & $57.13(47.02 \text { to } 67.23)^{* *}$ & $11.83(0.96 \text { to } 22.70)^{*}$ & $33.48(8.50 \text { to } 58.45)^{* *}$ & $66.81(52.71 \text { to } 80.91)^{* *}$ \\
\hline Stage 4 slope & $53.67(43.25 \text { to } 64.09)^{* *}$ & $2.17(-8.14$ to 12.49$)$ & $13.84(-11.94$ to 39.62$)$ & $72.31(58.93 \text { to } 85.70)^{* *}$ \\
\hline Stage 5 slope & $42.51(30.49 \text { to } 54.53)^{* *}$ & $2.51(-11.01$ to 16.04$)$ & $19.93(-9.66$ to 49.53$)$ & $71.03(53.46 \text { to } 88.60)^{* *}$ \\
\hline \multicolumn{5}{|c|}{ Variance-Covariance Matrix of Random Variables } \\
\hline \multicolumn{5}{|l|}{ Level 1 (within individuals) } \\
\hline Repeated measures variance & $236.21(181.30 \text { to } 307.73)^{* *}$ & $230.88(177.26 \text { to } 300.73)^{* *}$ & $1460.23(1121.52 \text { to } 1901.23)^{* *}$ & $387.77(297.60 \text { to } 505.25)^{* *}$ \\
\hline \multicolumn{5}{|l|}{ Level 2 (between individuals) } \\
\hline Variance & $0.1(0.02 \text { to } 0.16)^{*}$ & $0.01(0.02 \text { to } 0.11)^{*}$ & $0.2(0.01$ to 0.22$)$ & $0.1(0.05 \text { to } 0.28)^{*}$ \\
\hline -2 Restricted Log Likelihood & 1061.29 & 1054.06 & 1255.54 & 1123.73 \\
\hline Akaike's Information Criterion & 1079.29 & 1074.06 & 1273.54 & 1143.73 \\
\hline
\end{tabular}




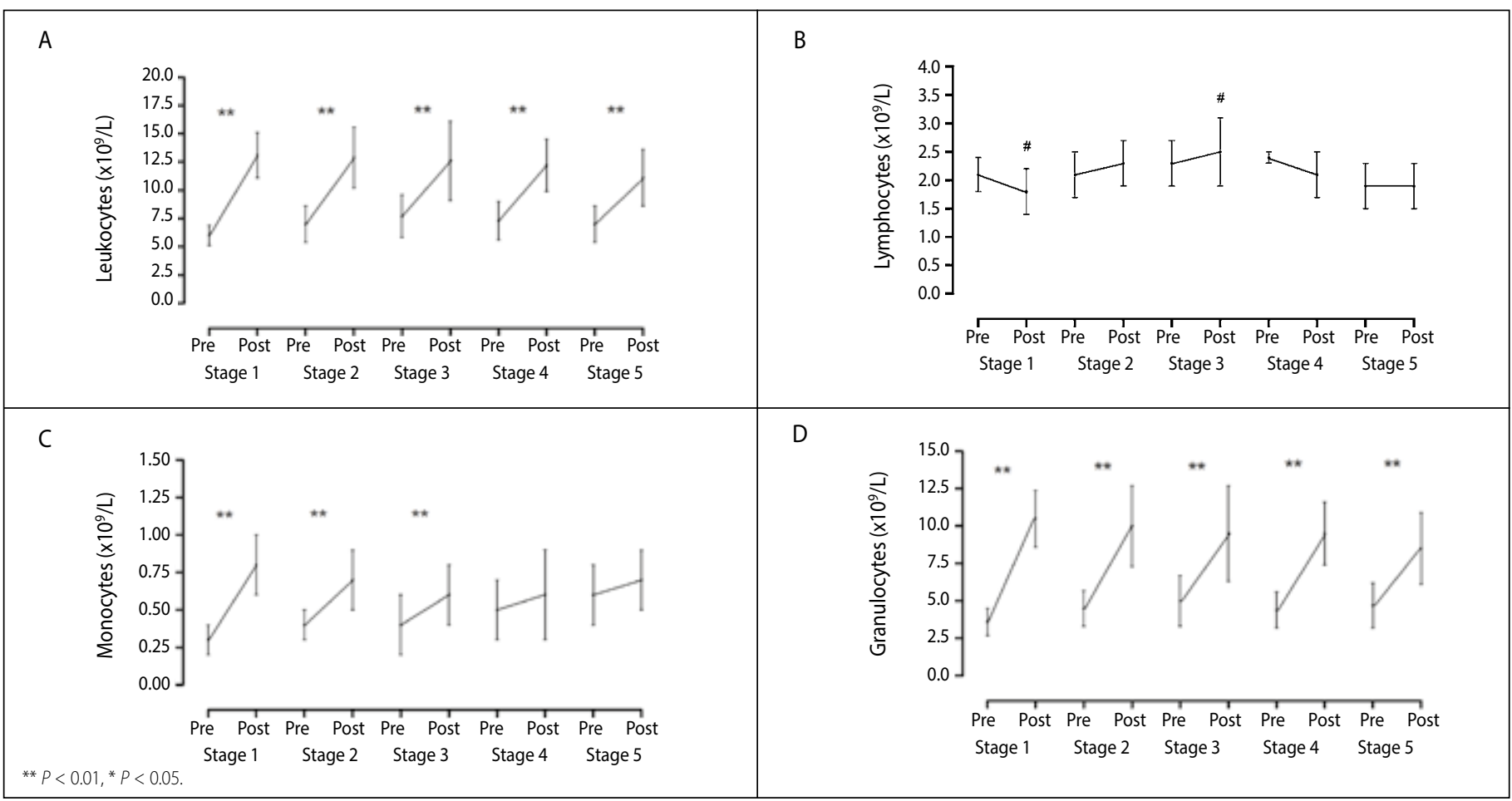

Figure 1. A pre- vs. post-stage change of leukocytes and subset counts in the peripheral blood at the five stages of the multi-stage ultra-marathon (A: leukocytes; B: granulocytes; C: lymphocytes; D: monocytes).

Table 3. Multilevel regression analysis of log transformed Erythrocytes, Haemoglobin, Haematocrit and Platelet changes within- and between-stages in the multi-stage ultramarathon.

\begin{tabular}{c|c|c|c|c|}
\hline & Erythrocytes & Haemoglobin & Haematocrit & \\
\hline Estimate (95\% Confidence Limits) & & & & \\
\hline Intercept & $161.10(157.23 \text { to } 164.96)^{* *}$ & $279.30(276.93 \text { to } 281.68)^{* *}$ & $382.39(380.02 \text { to } 384.74)^{* *}$ & $540.15(531.1 \text { to } 549.1)^{* *}$ \\
\hline Between stages linear change & $0.08(-3.38$ to 3.54$)$ & $-0.08(-0.14 \text { to }-0.20)^{* *}$ & $-0.10(-0.16 \text { to }-0.03)^{* *}$ & $0.15(-8.02$ to 8.32$)$ \\
\hline Between stages quadratic change & & & & \\
\hline Within stages slopes (pre- vs post- differences) & & & & \\
\hline Stage 1 slope & $0.12(-2.90$ to 3.14$)$ & $2.29(-1.50$ to 6.08$)$ & $1.48(-2.27$ to 5.24$)$ & $15.49(8.90 \text { to } 22.07)^{* *}$ \\
\hline Stage 2 slope & $0.31(-2.42$ to 3.04$)$ & $1.90(-1.52$ to 5.33$)$ & $1.45(-1.94$ to 4.85$)$ & $16.99(11.02 \text { to } 22.95)^{* *}$ \\
\hline Stage 3 slope & $2.51(-.42$ to 5.44$)$ & $-0.40(-3.76$ to 2.95$)$ & $0.11(-3.22$ to 3.45$)$ & $14.76(8.37 \text { to } 21.15)^{* *}$ \\
\hline Stage 4 slope & $0.23(-2.79$ to 3.25$)$ & $0.16(-3.42$ to 3.74$)$ & $-0.36(-3.91$ to 3.19$)$ & $10.15(3.56 \text { to } 16.73)^{* *}$ \\
\hline Stage 5 slope & $-0.08(-3.58$ to 3.43$)$ & $-0.20(-4.17$ to 3.77$)$ & $-0.51(-4.45$ to 3.43$)$ & $8.53(0.87 \text { to } 16.17)^{*}$ \\
\hline Variance-Covariance Matrix of Random Variables & & & & \\
\hline Level 1 (within individuals) & & & & \\
\hline Repeated measures variance & $19.57(14.63 \text { to } 26.18)^{* *}$ & $33.56(26.21 \text { to } 42.46)^{* *}$ & $33.09(25.85 \text { to } 42.37)^{* *}$ & $92.99(69.55 \text { to } 124.33)^{* *}$ \\
\hline Level 2 (between individuals) & & & & \\
\hline Variance & $38.5(20.64 \text { to } 71.67)^{* *}$ & $0.0(0.00 \text { to } 0.02)^{*}$ & $0.0(0.00 \text { to } 0.17)^{*}$ & $215.4(116.73 \text { to } 397.37)^{* *}$ \\
\hline -2 Restricted Log Likelihood & 900.71 & 919.42 & & 918.21 \\
\hline Akaike's Information Criterion & 918.71 & 937.42 & & 1098.22 \\
\hline
\end{tabular}

** $P \leq 0.01 ; * P \leq 0.05$

\section{DISCUSSION}

The purpose of the study was to monitor daily haematological assessment in a 230-km multistage ultra-marathon competition conducted in a hot environment. When comparing pre- to post-stage values across the MSUM, results showed significant differences predominantly in whole blood leukocytes, granulocytes and platelets counts for the five stages of the race. For monocyte counts the pre- to post-stage increases were observed in the first three stages of the competition. The magnitude of within stage changes was substantial with a range of increments in leukocytes, monocytes and granulocytes responses among 33\% to 104\%.

The magnitude of differences between pre- to post-stage tended to be higher in the first stage and decreased thereafter.

First, we suggest that athletes may have a decrease in immune function in the early stages of the MSUM probably with some transient risk of infectious. The proliferative capacity of lymphocytes is a key event in the immune response, and the host capacity to respond to an immunological challenge can be significantly compromised if lymphocyte proliferation is not adequate. This may result in increased risk of infectious diseases and autoimmune disorders. ${ }^{19}$ We observe lymphocytosis just in S3 of the MSUM. Probably this reflect a post-stage salivary cortisol concentration lower (54\%) in this stage. ${ }^{20}$ The increase in monocyte counts pre- to post-Stage occurred on S1 to S3 and it is consistent with an inflammatory response to exercise, probably caused by tissue injury. Of the note, Gill and co-authors mentioned 1 runner that reported upper respiratory symptoms on S3 and continued, varying in severity, until 7 days after the ultra-marathon competition.

Second, a physiological adaptation to the exercise effort and heat, that could be mediated by an increase in anti-inflammatory cytokine 


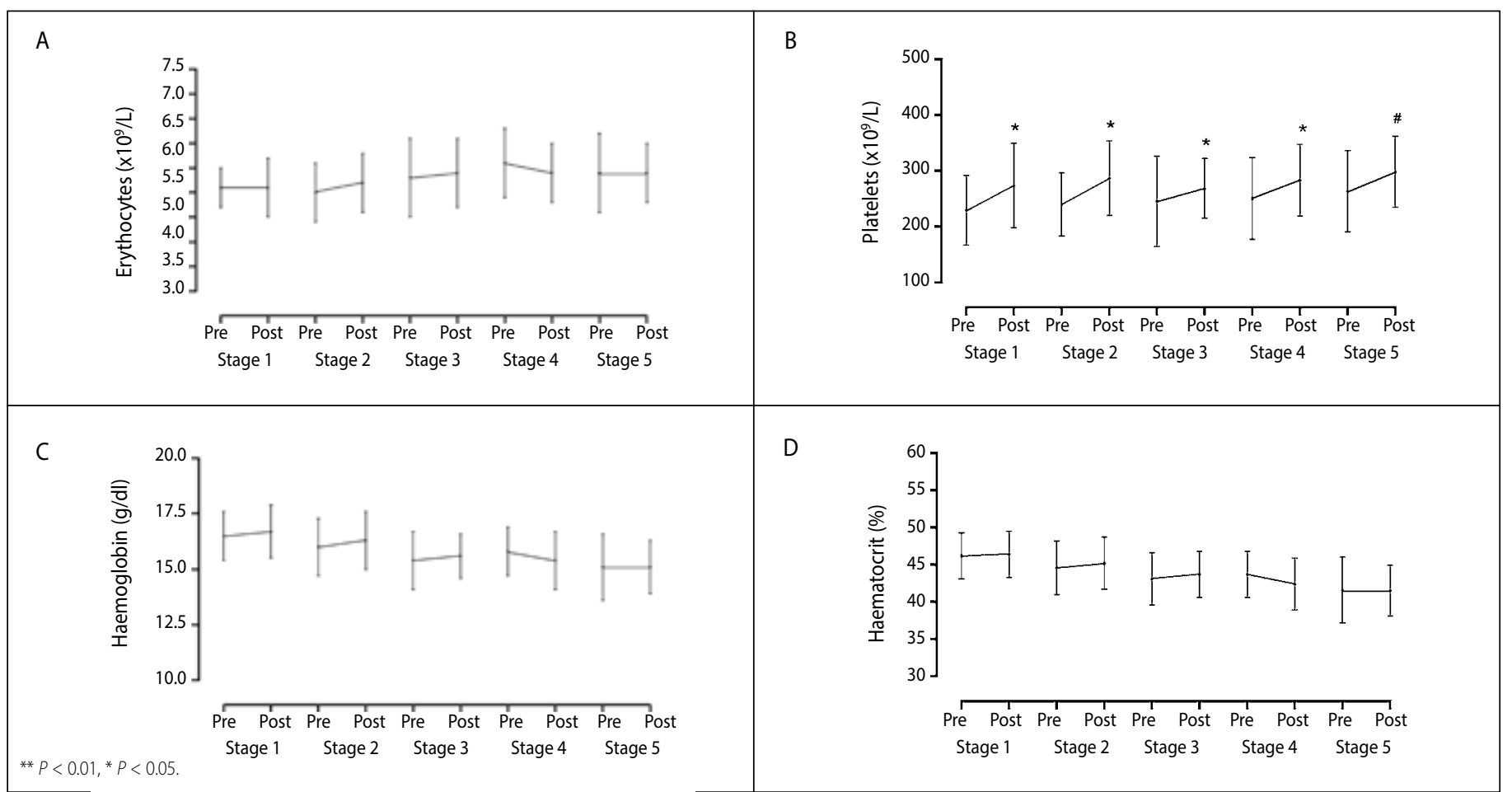

Figure 2. Pre- vs. post-stage changes of erythrocytes in the peripheral blood at the five stages of the multi-stage ultra-marathon (A: erytrocytes; B: platelets; C: haemoglobin; D: haematocrit).

secretion. ${ }^{21}$ Excessive strenuous exercise, especially in hot ambient conditions, results in a cytokine-mediated systemic inflammatory response ${ }^{22}$ like the cytokine profile of acute infectious episodes. A laboratory controlled study observed pre- to post-stage increases for pro- (e.g., IL-6, IL-1 $\beta$, TNF- $\alpha$, IFN- $\gamma$ ) and anti-inflammatory (IL-10 and IL-1 ra) cytokine production after a MSUM. ${ }^{21}$ Another most recent publication also showed that the ultra-endurance exercise caused significant increases in plasma IL-6, IL-10, IL-18 and TNF-a. ${ }^{23}$ Regardless of the source, the main function of IL-10 seems to be the downregulation of adaptive immune responses and reduction of inflammation-induced tissue damage. Thus, L-10 is a potent promoter of an anti-inflammatory state. ${ }^{24}$ Maybe because this increase of IL-10 reported by Costa and co-authors ${ }^{21}$ provoke a physiological adaptation to the exercise effort and heat, declining the magnitude of these haematological changes in the following stages 4 and 5 of MSUM.

The magnitude of pre- to post-stage differences for platelets ranged from $9 \%$ to $17 \%$, with the higher changes observed in the first two stages and decreasing until the last stage. The rise in number of circulating platelets accompanies the rise of leukocytes. This may be explained by an inflammatory-like reaction associated with endurance effort, but it does not indicate a pathological condition for individuals, even during extreme performance. ${ }^{5}$ Hanke et al. ${ }^{25}$ reported platelet concentrations significantly altered during marathon and triathlon events (239.3 \pm $36.5 \mathrm{ul}^{-1} \mathrm{l}$ before to $286.0 \pm 42.5 \mathrm{ul}^{-1} \mathrm{l}$ after marathon competition). The mechanism for platelet activation was explained by mechanical stress on thrombocytes and/or inflammation. However, in the study of the 32 participants of the 2005 Boston Marathon, no statistically or clinically significant changes in platelet counts were observed. The elevation of platelet counts could be due to dehydration, or it could be part of the acute phase response to tissue injury. ${ }^{26}$

Although to pre- to post-stage changes in both haemoglobin and haematocrit were observed, there was a significant decrease in both indicators across the MSUM, consistent with previous results by us $^{16}$ and others. ${ }^{5}$ Decreases in haemoglobin and haematocrit may be expected in relation to increased plasma volume during prolonged exer-

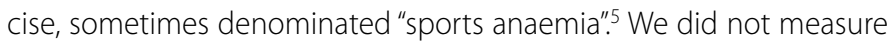

extracellular plasma hypervolemia directly (plasma volume expansion). However, changes in whole blood haemoglobin and haematocrit have previously been used to estimate plasma volume expansions ${ }^{17}$ and this has been reported as a valid and reliable method of indirectly establishing plasma volume expansion during heat acclimation protocols. ${ }^{27}$ Costa and co-authors attributed to heat-stress the changes in plasma volume, when significant increases in plasma volume were observed after exercise-bouts at $30^{\circ} \mathrm{C}$ or more..$^{13}$

The intravascular haemolysis from mechanical trauma, osmotic and oxidative damage to erythrocytes may also explain the changes in haemoglobin and haematocrit across the MSUM. ${ }^{28}$ However, the unchanged responses in erythrocytes counts across the race in the present study suggests that decreases in haemoglobin and haematocrit in response to intermittent exposure to prolonged exercise may be due to changes in plasma volume. Thus, changes in haemoglobin and haematocrit across the MSUM do not seem to indicate a pathological condition, but rather changes in body water and potentially hydration status. ${ }^{13}$

The results of the present study were obtained in a competitive context; thus, conditions of the race were homogeneous for all athletes and provide a model of reference for physiological responses to extreme effort.

\section{CONCLUSIONS}

Altogether, the results indicate that exposure to this kind of competition have a higher impact on leukocyte populations responses in the initial stages of the race. Combined with the observed variation in platelet responses within stages across the race, ultra-endurance runners may have inflammatory responses caused by multiple factors including tissue injury and intestinal originated endotoxaemia particularly in the initial stages of the races, with probable implications to performance and health. Appropriate hydration maintenance, heat acclimation before the race and management of potential situations that may lead to bacterial or virus exposure is recommended. At the end, the haematological changes associated with ultra-endurance running within multistage events may be useful to prevent impairment in immune function, and the occurrence of relevant sub-clinical and clinical issues. 


\section{ACKNOWLEDGMENTS}

Firstly, the authors would like to thank all the ultra-endurance runners that volunteered to participate in this study. The authors acknowledge the Al Andalus Ultimate Trail (www.alandalus-ut.com) race directors Paul Bateson and Barbara Price; and Team Axarsport SL: Michelle Cutler and Eric Maroldo, for assisting and supporting various aspects of this study. The authors also acknowledge Volker Scheer, Encarna Valero-Burgos, Nina Godson, Sue Cresswell, and Tim Morse for phlebotomy during the research design implementation; Emily Freeth, Edel Barrett, Jessica Waterman, Slawomir Marczak, Samantha Gill, and Joanne Hankey for their support during the process of sample and data collection. The study was partly funded by Coventry University as part of Dr. Ricardo
Costa's Applied Research Fellowship, and Faculty of Sport Sciences and Physical Education, University of Coimbra. Also, the present manuscript was accomplished with support from the CAPES, Coordination for the Improvement of Higher Education Personnel, Brazil.

Luciele Guerra Minuzzi is currently receiving a grant (\#1417/13-4) from CAPES, Coordination for the Improvement of Higher Education Personnel, Brazil. Ana Maria Teixeira and Luiz Rama are registered in the unit UID/DTP/04213/2016.

All authors declare no potential conflict of interest related to this article.

AUTHORS' CONTRIBUTIONS: Each author made significant individual contributions to this manuscript. LGM (0000-0002-9342-5563)*: writing of the article, data analysis; AMT (0000-0003-1498-949X)*: revision and writing of the article; HMC (0000-0002-2855-0296)*: statistical analysis, writing and participation in the intellectual concept of the article; RJC (0000-0003-3069-486X)*: review of the article; LR (0000-0002-9619-8618)*: data collection, review. All authors contributed to the intellectual concept of the study and approved the final version of the manuscript. ${ }^{*} \mathrm{ORCID}$ (Open Researcher and Contributor ID).

\section{REFERENCES}

1. Knechtle B. Ultramarathon runners: nature or nurture? Int J Sports Physiol Perform 2012 [Internet];7(4):310-2. Available from: http://www.ncbi.nlm.nih.gov/pubmed/23197583.

2. Krabak BJ, Waite B, Lipman G. Injury and illnesses prevention for ultramarathoners. Curr Sports Med Rep. 21013 [Internet];12(3):183-9. Available from: http://www.ncbi.nlm.nih.gov/pubmed/23669089.

3. Knoth C, Knechtle B, Rüst CA, Rosemann T, Lepers R. Participation and performance trends in multistage ultramarathons-the "Marathon des Sables" 2003-2012. Extrem Physiol Med. 2012 [Internet];1(1):13. Available from: http://www.pubmedcentral.nih.gov/articlerender.fcgi?artid=3710135\&tool=pmcentr ez\&rendertype=abstract.

4. Bain BJ, Phillips D, Thomson K, Richardson D, Gabriel I. Investigation of the effect of marathon running on leucocyte counts of subjects of different ethnic origins: relevance to the aetiology of ethnic neutropenia. $\mathrm{Br}$ J Haematol. 2000 [Internet];108(3):483-7. Available from: http://www.ncbi.nlm.nih.gov/pubmed/10759703.

5. Banfi G, Roi GS, Dolci A, Susta D. Behaviour of haematological parameters in athletes performing marathons and ultramarathons in altitude ('skyrunners'). Clin Lab Haematol. 2004 [Internet];26(6):373-7. Available from: http://www.ncbi.nlm.nih.gov/pubmed/15595993.

6. Santos VC, Levada-Pires AC, Alves SR, Pithon-Curi TC, Curi R, Cury-Boaventura MF. Changes in lymphocyte and neutrophil function induced by a marathon race. Cell Biochem Funct. 2013 [Internet];31(3):237-43. Available from: http://onlinelibrary.wiley.com/store/10.1002/cbf.2877/asset/ cbf2877.pdf?v=1\&t=hsxbeb2r\&s=089899fcd57288f63f4cfe29a50861367300a2e9.

7. Smith JE, Garbutt G, Lopes P, Pedoe DT. Effects of prolonged strenuous exercise (marathon running) on biochemical and haematological markers used in the investigation of patients in the emergency department. Br J Sports Med. 2004 [Internet];38(3):292-4. Available from: http://dx.doi.org/10.1136/ bjsm.2002.002873.

8. Murray A, Costa RJ. Born to run. Studying the limits of human performance. BMC Med 2012 [Internet];10:76. Available from: http://www.biomedcentral.com/1741-7015/10/76/

9. Mairbäurl H. Red blood cells in sports: effects of exercise and training on oxygen supply by red blood cells. Front Physiol 2013 [Internet];4:332. Available from: http://www.pubmedcentral.nih. gov/articlerender.fcgi?artid=3824146\&tool=pmcentrez\&rendertype=abstract.

10. Gwozdzinski K, Pieniazek A, Brzeszczynska J, Tabaczar S, Jegier A. Alterations in red blood cells and plasma properties after acute single bout of exercise. Sci World J. 2013;2013:168376.

11. El-Sayed MS, Ali N, El-Sayed Ali Z. Haemorheology in exercise and training. Sports Med. 2005;35(8):649-70.

12. Walsh NP, Whitham M. Exercising in environmental extremes: a greater threat to immune function? Sports Med. 2006;36(11):941-76.

13. Costa RJ, Crockford MJ, Moore JP, Walsh NP. Heat acclimation responses of an ultra-endurance running group preparing for hot desert-based competition. Eur J Sport Sci 2014 [Internet];14(Suppl 1):S131-41. Available from: http://www.ncbi.nlm.nih.gov/pubmed/24444197.

14. Wendt $D$, Van Loon $L$, Lichtenbelt WD. Thermoregulation during exercise in the heat: strategies for maintaining health and performance. Sports Med. 2007;37(8):669-82.

15. Hargreaves M. Physiological limits to exercise performance in the heat. J Sci Med Sport . 2008[Internet];11(1):66-71. Available from: http://www.ncbi.nlm.nih.gov/pubmed/17720623.
16. Rama LM, Minuzzi LG, Carvalho HM, Costa RJ, Teixeira AM. Changes of hematological markers during a multi-stage ultra-marathon competition in the heat. Int J Sports Med . 2016 [Internet];37(2):104-11. Available from: http://www.ncbi.nlm.nih.gov/pubmed/26509375.

17. Dill DB, Costill DL. Calculation of percentage changes in volumes of blood, plasma, and red cells in dehydration. J Appl Physiol. 1974 [Internet]; 37(2):247-8. Available from: http://www.ncbi.nlm.nih. gov/pubmed/4850854.

18. Hopkins WG, Marshall SW, Batterham AM, Hanin J. Progressive statistics for studies in sports medicine and exercise science. Med Sci Sports Exerc. 2009 [Internet];41(1):3-12. Available from: http://content. wkhealth.com/linkback/openurl?sid=WKPTLP:landingpage\&an=00005768-200901000-00002.

19. Tossige-Gomes R, Ottone VO, Oliveira PN, Viana DJ, Araujo TL, Gripp FJ, et al. Leukocytosis, muscle damage and increased lymphocyte proliferative response after an adventure sprint race. Braz J Med Biol Res. 2014 [Internet];47(6)492-8. Available from: http://www.scielo.br/scielo. php?script=sci_arttext\&pid=S0100-879X2014000600492\&Ing=en\&nrm=iso\&tIng=en.

20. Gill SK, Teixeira AM, Rama L, Rosado F, Hankey J, Scheer V, et al. Salivary antimicrobial protein responses during multistage ultramarathon competition conducted in hot environmental conditions. Appl Physiol Nutr Metab. 2013 [Internet];38(9):977-87. Available from: http://dx.doi.org/10.1139/ apnm-2013-0005.

21. Gill SK, Ana T, Rama L, Rosado F, Hankey J, Scheer V, et al. Circulatory endotoxin concentration and cytokine profile in response to exertional-heat stress during a multi-stage ultra-marathon competition. Exerc Immunol Rev. 2015;21:114-28.

22. Suzuki K, Nakaji S, Yamada M, Liu Q, Kurakake S, Okamura N, et al. Impact of a competitive marathon race on systemic cytokine and neutrophil responses. Med Sci Sports Exerc. 2003;35(2):348-55.

23. Krzemiński K, Buraczewska M, Miśkiewicz Z, Dąbrowski J, Steczkowska M, Kozacz A, et al. Effect of ultra-endurance exercise on left ventricular performance and plasma cytokines in healthy trained men. Biol Sport. 2016 [Internet];33(1):63-9. Available from: http://www.pubmedcentral.nih.gov/ articlerender.fcgi?artid $=4786588 \&$ tool $=$ pmcentrez\&rendertype $=$ abstract.

24. Saraiva M, O'Garra A. The regulation of IL-10 production by immune cells. Nat Rev Immunol. 2010 [Internet];10(3):170-81. Available from: http://www.ncbi.nlm.nih.gov/pubmed/20154735.

25. Hanke AA, Staib A, Görlinger K, Perrey M, Dirkmann D, Kienbaum P. Whole blood coagulation and platelet activation in the athlete: a comparison of marathon, triathlon and long distance cycling. Eur J Med Res. 2010 [Internet]; 15(2):59-65. Available from: http://dx.doi.org/10.1 186/2047-783X-15-2-59.

26. Kratz A, Wood MJ, Siegel AJ, Hiers JR, Van Cott EM. Effects of marathon running on platelet activation markers: direct evidence for in vivo platelet activation. Am J Clin Pathol. 2006 [Internet];125(2):296-300. Available from: http://ajcp.ascpjournals.org/cgi/doi/10.1309/PRF5N7P2XM6E243H.

27. Garrett AT, Rehrer NJ, Patterson MJ. Induction and decay of short-term heat acclimation in moderately and highly trained athletes. Sports Med. 2011;41(9):757-71.

28. Robach $P$, Boisson R-C, Vincent L, Lundby C, Moutereau S, Gergelé L, et al. Hemolysis induced by an extreme mountain ultra-marathon is not associated with a decrease in total red blood cell volume. Scand J Med Sci Sports. 2014 [Internet];24(1):18-27. Available from: http://dx.doi. org/10.1111/j.1600-0838.2012.01481.x 